\title{
The Effects of Cinepazide on the Content, Biosynthesis and Turnover of Noradrenaline, Dopamine and 5-Hydroxytryptamine in the Rat Brain under Room Air and Hypoxia
}

\author{
Soichi MIWA, Motokazu FUJIWARA, Ken LEE and \\ Motohatsu FUJIWARA* \\ Department of Pharmacology, Faculty of Medicine, Kyoto University, \\ Kyoto 606, Japan
}

Accepted February 8, 1986

\begin{abstract}
The effects of cinepazide, a vasodilator, on the content, biosynthesis and turnover of noradrenaline (NA), dopamine (DA) and 5-hydroxytryptamine $(5-\mathrm{HT})$ in the rat brain were examined under room air and hypoxia $\left(10 \% \mathrm{O}_{2}, 90 \%\right.$ $\mathrm{N}_{2}$ ). Under room air, cinepazide had no significant effects on the content of NA, DA, 5-HT and 5-hydroxyindoleacetic acid (5-HIAA), the accumulation of 3.4-dihydroxyphenylalanine (DOPA) and 5-hydroxytryptophan (5-HTP) after central decarboxylase inhibition, and the depletion of NA. DA and 5-HT after synthesis inhibition. After 2 hr-exposure to hypoxia, the content of NA, 5-HT and 5-HIAA was decreased, whereas the content of DA was unchanged. The accumulation of DOPA and 5-HTP was decreased. The depletion of DA and 5-HT was inhibited by hypoxia, whereas the depletion of NA was unaffected. Under hypoxic conditions, cinepazide had no effects on the content of NA, DA and $5-H T$, the accumulation of DOPA and 5-HTP, and the depletion of NA and DA, whereas cinepazide increased both the rate of 5 -HT depletion and the content of 5 -HIAA. The present data suggest that cinepazide selectively stimulates the functional activities of $5-\mathrm{HT}$ neurons in the brain, which are depressed by hypoxia.
\end{abstract}

As previously reported, cinepazide has a vasodilating action (1) and increases the blood flow through the brain $(2,3)$ and peripheral organs such as cardiac muscle, skeletal muscle and kidney $(1,2)$. These actions of cinepazide may be partly mediated by adenosine and cyclic AMP (1). Therefore, this drug is widely being used for the treatment of cerebral vascular disorders and is reported to be effective $(3,4)$. However, its effects on the neuronal activities in the brain are totally unknown. On the other hand, it has been reported that hypoxia decreases the biosynthesis of neurotransmitters in the brain such as noradrenaline (NA), dopamine (DA) and 5-hydroxytryptamine (5-HT) (58 ) and the turnover rates of DA and 5-HT (7-9).

* To whom reprint requests should be addressed.
In the present study, we examined the effects of cinepazide on the content, biosynthesis and turnover of NA, DA and 5-HT in the brain under room air and hypoxia to clarify the effects of cinepazide on the activities of monoamine neurons in the brain.

\section{Materials and Methods}

Exposure to hypoxia: Male Wistar rats, weighing $170-200 \mathrm{~g}$, were exposed to a mixture of $10 \%$ oxygen and $90 \%$ nitrogen for various periods in a hypoxic chamber designed in our laboratory. The gas mixture was continuously passed through the chamber at a flow rate of $3 \mathrm{l} / \mathrm{min}$. The gas mixture in the chamber was circulated through a $\mathrm{CO}_{2}$ scrubber containing Soda Lime to prevent accumulation of $\mathrm{CO}_{2}$. The concentration of oxygen in the hypoxic chamber was continuously monitored with 
an oxygen measuring device (Riken Keiki, Tokyo, Japan). The control rats were exposed to room air in the same type of chamber. Both hypoxic and control rats were kept at a constant room temperature of $25 \pm 0.5^{\circ} \mathrm{C}$ and were deprived of food and water during the experimental periods to avoid the influence of nutritional changes. One or two hours after exposure to hypoxia or room air, the rats were decapitated and the whole brains were rapidly removed.

Assay of NA, DA and 3,4-dihydroxyphenylalanine (DOPA): The content of NA. DA and DOPA was estimated using highperformance liquid chromatography (HPLC) with electrochemical detection according to the method of Keller et al. (10) with a minor modification (11). The whole brain was homogenized in 10 volumes (wt./vol.) of $0.1 \mathrm{M}$ perchloric acid containing $1 \mathrm{mg} / \mathrm{ml}$ sodium bisulfite and $1 \mathrm{mM}$ EDTA, and the homogenate was centrifuged at $27,500 \times \mathrm{g}$ for $10 \mathrm{~min}$ at $4^{\circ} \mathrm{C}$. After centrifugation, to $3 \mathrm{ml}$ of the supernatant were added $100 \mathrm{ng}$ of dihydroxybenzylamine (DHBA) as an internal standard, $3 \mathrm{ml}$ of $1 \mathrm{M}$ Tris- $\mathrm{HCl}$ buffer $(\mathrm{pH} 8.6)$ to adjust the $\mathrm{pH}$ to $8.3-8.4$, and $25 \mathrm{mg}$ of acid-washed alumina. The mixture was vigorously shaken for $20 \mathrm{~min}$ to adsorb NA, DA and DOPA on the alumina, and then, it was left to stand for about five minutes. The supernatant was discarded, and the alumina was washed three times with cold redistilled water. After washing, NA and DA were eluted from the alumina with $0.1 \mathrm{M}$ $\mathrm{HCl}$, and DOPA was eluted with $0.5 \mathrm{M} \mathrm{HCl}$. An aliquot of the eluate was injected onto HPLC. The chromatographic mobile phase was $0.1 \mathrm{M}$ potassium phosphate buffer $(\mathrm{pH}$ 3.1) containing $10 \%$ methanol, $100 \mu \mathrm{M}$ EDTA and $300 \mathrm{mg} / \mathrm{l}$ sodium heptane sulfonate, which was pumped at $1.0 \mathrm{ml} / \mathrm{min}$. The potential of the electrochemical detector was set at $+0.7 \mathrm{~V}$ against the $\mathrm{Ag} / \mathrm{AgCl}$ reference electrode. The working electrode was of glassy carbon and the auxiliary electrode was of stainless-steel. The content of NA in tissue samples was calculated according to the equation: $\mathrm{NA}$ ( $\mathrm{ng} / \mathrm{g}$ tissue $)=100 \mathrm{ng} \times$ peak height NA/peak height DHBAxstandard ratio $\mathrm{DHBA} / \mathrm{NA} \times 1 / \mathrm{g}$ tissue. The content of DOPA and DA was similarly calculated.
Assay of 5-hydroxytryptophan (5-HTP), 5-HT and 5-hydroxyindoleacetic acid (5HIAA): The content of 5-HTP, 5-HT and 5HIAA in the brain was measured using HPLC with electrochemical detection according to the method of Reinhard et al. (12). The whole brain was homogenized in 10 volumes (wt./ vol.) of $0.1 \mathrm{M}$ perchloric acid containing $1 \mathrm{mg} / \mathrm{ml}$ sodium bisulfite and $1 \mathrm{mM}$ EDTA, and the homogenate was centrifuged at $27,500 \times \mathrm{g}$ for $10 \mathrm{~min}$ at $4^{\circ} \mathrm{C}$. After centrifugation, the supernatant was filtered through a membrane filter (pore size, $0.45 \mu \mathrm{m}$ ), and the filtrate was directly injected onto HPLC. The chromatographic mobile phase was $0.1 \mathrm{M}$ sodium acetate buffer ( $\mathrm{pH}$ 5.0) containing $10 \%$ methanol and $100 \mu \mathrm{M}$ EDTA, which was pumped at $1.0 \mathrm{ml} / \mathrm{min}$. The potential of the electrochemical detector was set at $+0.45 \mathrm{~V}$ against the $\mathrm{Ag} / \mathrm{AgCl}$ reference electrode.

High-performance liquid chromatography system: The HPLC system consisted of a Hitachi LC 655 pump, a Rheodyne Model 655 sample injector, a Bioanalytical System LC $4 \mathrm{~B}$ electrochemical detector and a $5 \mathrm{C}_{18}$ reverse phase column $(4.6 \times 150 \mathrm{~mm})$.

Estimation of in vivo tyrosine and tryptophan hydroxylation: The in vivo tyrosine and tryptophan hydroxylations were estimated by measuring the accumulation of DOPA and 5-HTP after the inhibition of aromatic Lamino acid decarboxylase by m-hydroxybenzylhydrazine (NSD 1015), as described by Carlsson et al. (13). Rats were intraperitoneally injected with saline or cinepazide solution and ten minutes later, the rats were exposed to room air or hypoxia. After $1.5 \mathrm{hr}$ exposure, the rats were injected with NSD $1015(100 \mathrm{mg} / \mathrm{kg})$, and the exposure was further continued. Thirty minutes after the injection of NSD 1015, the rats were decapitated, and DOPA and 5-HTP accumulated in the whole brain were determined. Since the content of DOPA and 5HTP in the absence of treatment with NSD 1015 was negligible, the accumulation of DOPA and 5-HTP was represented by the content of DOPA and 5-HTP after NSD 1015 treatment.

Estimation of the turnover rates of NA and DA: The turnover rates of NA and DA were 
estimated by measuring the decrease in the content of NA and DA after the inhibition of tyrosine hydroxylase by $\alpha$-methyl-p-tyrosine $(\alpha-M T)$, as reported by Brodie et al. (14). The content of NA and DA decreased exponentially up to $2 \mathrm{hr}$ after the injection of $\alpha$ MT $(250 \mathrm{mg} / \mathrm{kg}$ ) under room air or hypoxia. Therefore, to obtain the turnover rate of NA and DA, rats were intraperitoneally injected with saline or cinepazide solution, and ten minutes later, the rats were injected with $\alpha-\mathrm{MT}$, immediately followed by exposure to room air or hypoxia. After $2 \mathrm{hr}$-exposure, the rats were decapitated and the content of NA and DA in the brain was determined.

Estimation of the turnover rate of $5-\mathrm{HT}$ : The turnover rate of $5-\mathrm{HT}$ was estimated by measuring the decrease in the content of 5 HT after the inhibition of tryptophan hydroxylase by 6 -fluorotryptophan (6-FT) as described by McGeer et al. (15). After the intraperitoneal injection of 6-fluorotryptophan $(200 \mathrm{mg} / \mathrm{kg})$, the content of $5-\mathrm{HT}$ decreased exponentially at least up to $1 \mathrm{hr}$ under room air or hypoxia. Therefore, to obtain the turnover rate of $5-\mathrm{HT}$, rats were intraperitoneally injected with saline or cinepazide solution, and ten minutes later. the rats were injected with $6-\mathrm{FT}(200 \mathrm{mg} /$ $\mathrm{kg}$ ), immediately followed by exposure to room air or hypoxia. After $1 \mathrm{hr}$-exposure, the rats were decapitated and the content of 5 HT was determined.

Drugs: Drugs were obtained from the following sources: L-3,4-dihydroxyphenylalanine (DOPA), 5-hydroxy-L-tryptophan (5-
HTP), dopamine (DA) hydrochloride, Lnoradrenaline (NA) bitartrate and 5hydroxytryptamine (5-HT) creatinine sulfate from Wako Pure Chemical Industries, Ltd. Osaka, Japan; 5-hydroxyindoleacetic acid (5HIAA), 3,4-dihydroxybenzylamine (DHBA) dihydrobromide and m-hydroxybenzylhydrazine (NSD 1015) dihydrochloride from Aldrich. Milwaukee, WI, U.S.A.; $\alpha$-methyl-ptyrosine $(\alpha-\mathrm{MT})$ methylester and 6-fluoroDL-tryptophan (6-FT) from Sigma, St. Louis, MO, U.S.A. Cinepazide was a gift from Daiichi Seiyaku Co. Ltd., Tokyo, Japan.

Statistical analysis: All results are expressed as means \pm S.E. Student's $t$-test for unpaired comparison was used for statistical analyses, and a probability level of $\mathrm{P}<0.05$ was considered to be statistically significant.

\section{Results}

Table 1 shows the effects of cinepazide on the content of NA, DA and 5-HT in the rat whole brain under room air and hypoxia. Under room air, $4 \mathrm{mg} / \mathrm{kg}-150 \mathrm{mg} / \mathrm{kg}$ of cinepazide produced no significant changes in the content of NA, DA and 5-HT. After $2 \mathrm{hr}$ exposure to hypoxia, the content of NA and 5 -HT was decreased significantly as compared with the values obtained under room air, whereas the content of DA was unchanged. Under hypoxic conditions, 4 $\mathrm{mg} / \mathrm{kg}-150 \mathrm{mg} / \mathrm{kg}$ of cinepazide produced no significant changes in the content of NA, DA and $5-H T$.

Table 2 shows the effects of cinepazide on the depletion of NA, DA and 5-HT in the rat

Table 1. The effects of cinepazide on the content of NA, DA and 5-HT under room air and hypoxic conditions

\begin{tabular}{lcccccc}
\hline & \multicolumn{3}{c}{ Monoamine content (ng/g tissue) } \\
Treatment & \multicolumn{2}{c}{ NA } & \multicolumn{2}{c}{ DA } & 5-HT \\
& Room air & Hypoxia & Room air & Hypoxia & Room air & Hypoxia \\
Saline & $320 \pm 6$ & $277^{\mathrm{a}} \pm 4$ & $815 \pm 12$ & $826 \pm 16$ & $410 \pm 11$ & $344^{\mathrm{a}} \pm 5$ \\
Cinepazide, $4 \mathrm{mg} / \mathrm{kg}$ & $318 \pm 7$ & $267^{\mathrm{a}} \pm 3$ & $805 \pm 14$ & $829 \pm 12$ & $389 \pm 17$ & $338^{\mathrm{b}} \pm 9$ \\
Cinepazide, $20 \mathrm{mg} / \mathrm{kg}$ & $323 \pm 6$ & $261^{\mathrm{a}} \pm 5$ & $819 \pm 16$ & $809 \pm 15$ & $395 \pm 13$ & $349^{\mathrm{b}} \pm 9$ \\
Cinepazide, $100 \mathrm{mg} / \mathrm{kg}$ & $310 \pm 5$ & $272^{\mathrm{a}} \pm 6$ & $813 \pm 15$ & $828 \pm 9$ & $387 \pm 10$ & $342^{\mathrm{b}} \pm 8$ \\
Cinepazide, $150 \mathrm{mg} / \mathrm{kg}$ & $318 \pm 6$ & $279^{\mathrm{a}} \pm 5$ & $820 \pm 14$ & $813 \pm 8$ & $423 \pm 10$ & $360^{\mathrm{a}} \pm 6$ \\
\hline
\end{tabular}

Ten minutes after the intraperitoneal injection of saline or cinepazide solution ( $4 \mathrm{mg} / \mathrm{kg}-150 \mathrm{mg} / \mathrm{kg}$ ). rats were exposed to room air or hypoxia. Two hours later, rats were decapitated and the content of NA, DA and 5-HT was determined as described under "Materials and Methods". The values are means \pm S.E. of six determinations. " $\mathrm{P}<0.01$; ${ }^{\mathrm{b}} \mathrm{P}<0.05$; significantly different from room air. 
whole brain after treatment with $\alpha$-MT or 6-FT under room air and hypoxia. Under room air, cinepazide had no significant effects on the depletion of NA, DA and 5-HT. After exposure to hypoxia, the depletion of NA was unchanged, whereas the depletion of DA and 5-HT was markedly retarded. Under hypoxic conditions, cinepazide had no significant effects on the depletion of NA and DA. In contrast, $100 \mathrm{mg} / \mathrm{kg}$ and $150 \mathrm{mg} / \mathrm{kg}$ of cinepazide counteracted the hypoxiainduced retardation of 5-HT depletion slightly but significantly.
To further examine the effects of cinepazide on the turnover rate of $5-\mathrm{HT}$, we determined the content of 5-HIAA under room air and hypoxia after pretreatment with cinepazide. Table 3 shows the effects of cinepazide on the content of 5-HIAA under room air and hypoxia. Cinepazide (4 mg/ $\mathrm{kg}-150 \mathrm{mg} / \mathrm{g}$ ) produced no significant changes in 5-HIAA content under room air. After exposure to hypoxia, the content of 5-HIAA was markedly decreased as compared with the values obtained under room air. Under hypoxic conditions, $100 \mathrm{mg} / \mathrm{kg}$ and $150 \mathrm{mg} / \mathrm{kg}$ of

Table 2. The effects of cinepazide on the depletion of NA. DA and 5-HT in the rat brain after treatment by $\alpha$-MT or 6-FT under room air and hypoxia

\begin{tabular}{|c|c|c|c|c|c|c|}
\hline & \multicolumn{6}{|c|}{ Monoamine content (ng/g tissue) } \\
\hline & \multicolumn{2}{|c|}{ NA } & \multicolumn{2}{|c|}{ DA } & \multicolumn{2}{|c|}{$5-\mathrm{HT}$} \\
\hline & Room air & Hypoxia & Room air & Hypoxia & Room air & Hypoxia \\
\hline No treatment & $327 \pm 9$ & & $829 \pm 22$ & & $415 \pm 9$ & \\
\hline $\begin{array}{l}\alpha-\mathrm{MT} \text { or } 6-\mathrm{FT}+ \\
\text { Saline }\end{array}$ & $180 \pm 9$ & $180 \pm 7$ & $332 \pm 13$ & $482^{a} \pm 10$ & $221 \pm 9$ & $297^{\prime \prime} \pm 8$ \\
\hline $\begin{array}{l}\alpha-\mathrm{MT} \text { or } 6-\mathrm{FT}+ \\
\text { Cinepazide, } 4 \mathrm{mg} / \mathrm{kg}\end{array}$ & $178 \pm 6$ & $184 \pm 5$ & $355 \pm 12$ & $461^{a} \pm 8$ & $225 \pm 10$ & $289 a \pm 9$ \\
\hline $\begin{array}{l}\alpha-\mathrm{MT} \text { or } 6-\mathrm{FT}+ \\
\text { Cinepazide, } 20 \mathrm{mg} / \mathrm{kg}\end{array}$ & $179 \pm 5$ & $190 \pm 11$ & $358 \pm 11$ & $466 " \pm 13$ & $224 \pm 12$ & $295^{a} \pm 7$ \\
\hline $\begin{array}{l}\alpha-\mathrm{MT} \text { or } 6-\mathrm{FT}+ \\
\text { Cinepazide, } 100 \mathrm{mg} / \mathrm{kg}\end{array}$ & $177 \pm 10$ & $180 \pm 6$ & $343 \pm 15$ & $486^{a} \pm 9$ & $238 \pm 6$ & $270^{a, b} \pm 4$ \\
\hline $\begin{array}{l}\alpha \text {-MT or } 6-\mathrm{FT}+ \\
\text { Cinepazide. } 150 \mathrm{mg} / \mathrm{kg}\end{array}$ & N.D. & N.D. & N.D. & N.D. & $226 \pm 9$ & $268^{a, b} \pm 5$ \\
\hline
\end{tabular}

Rats were intraperitoneally injected with saline or cinepazide solution. Ten minutes later, the rats were intraperitoneally injected with $\alpha-\mathrm{MT}(250 \mathrm{mg} / \mathrm{kg})$ or $6-\mathrm{FT}(200 \mathrm{mg} / \mathrm{kg})$ and exposed to room air or hypoxia. For the determination of the turnover rate of NA and DA, the rats were decapitated $2 \mathrm{hr}$ after exposure; and for the determination of the turnover rate of $5-\mathrm{HT}$, the rats were decapitated $1 \mathrm{hr}$ after exposure. The content of NA, DA and 5-HT was determined as described under "Materials and Methods". The values are means \pm S.E. of seven determinations. ": $P<0.01$, significantly different from room air. $b$ : $P<0.05$, significantly different from the ( $\alpha-M T$ or $6-F T+$ saline) group. N.D.: not determined.

Table 3. The effects of cinepazide on the content of 5-HIAA in the rat brain under room air and hypoxia

\begin{tabular}{|c|c|c|}
\hline \multirow[t]{2}{*}{ Treatment } & \multicolumn{2}{|c|}{ 5-HIAA content ( $\mathrm{ng} / \mathrm{g}$ tissue) } \\
\hline & Room air & Hypoxia \\
\hline Saline & $338 \pm 9$ & $216 \pm 7^{a}$ \\
\hline Cinepazide, $4 \mathrm{mg} / \mathrm{kg}$ & $343 \pm 11$ & $225 \pm 9:$ \\
\hline Cinepazide, $20 \mathrm{mg} / \mathrm{kg}$ & $329 \pm 8$ & $228 \pm 6^{i t}$ \\
\hline Cinepazide, $100 \mathrm{mg} / \mathrm{kg}$ & $358 \pm 12$ & $235 \pm 5^{a, b}$ \\
\hline Cinepazide, $150 \mathrm{mg} / \mathrm{kg}$ & $350 \pm 11$ & $239 \pm 7^{a} \cdot b$ \\
\hline
\end{tabular}

Ten minutes after the intraperitoneal injection of saline or cinepazide solution, rats were exposed to room air or hypoxia. Two hours later, the rats were decapitated and the content of 5-HIAA was determined as described under "Materials and Methods". The values are means \pm S.E. of six determinations. a: $P<0.01$, significantly different from room air. b: $P<0.05$, significantly different from saline. 
Table 4. The effects of cinepazide on the accumulation of DOPA and 5-HTP after treatment by NSD 1015 under room air and hypoxia

\begin{tabular}{lcccc} 
& \multicolumn{2}{c}{ DOPA and 5 -HTP accumulated $(\mathrm{ng} / \mathrm{g}$ tissue/30 min) } \\
& Room air & Hypoxia & R-HTP \\
RSD $1015+$ Saline & $180 \pm 2$ & $91 \pm 4^{*}$ & $167 \pm 4$ & $89 \pm 3^{*}$ \\
NSD $1015+$ & $178 \pm 2$ & $89 \pm 4^{*}$ & $153 \pm 5$ & $82 \pm 2^{*}$ \\
Cinepazide, $100 \mathrm{mg} / \mathrm{kg}$ & & & \\
\hline
\end{tabular}

Rats were intraperitoneally injected with saline or cinepazide solution $(100 \mathrm{mg} / \mathrm{kg})$. Ten minutes later, the rats were exposed to room air or hypoxia. After $1.5 \mathrm{hr}$-exposure, the rats were intraperitoneally injected with NSD $1015(100 \mathrm{mg} / \mathrm{kg})$, and the exposure was further continued. Thirty minutes after the injection of NSD 1015, the rats were decapitated and the DOPA and 5-HTP accumulated were determined as described under "Materials and Methods". The values are means \pm S.E. of seven determinations. *: $\mathrm{P}<001$, significantly different from room air.

cinepazide produced a significant increase in the content of 5-HIAA.

Table 4 shows the effects of cinepazide on the accumulation of DOPA and 5-HTP in the brain after treatment with NSD 1015 under room air and hypoxia. Under room air, $100 \mathrm{mg} / \mathrm{kg}$ of cinepazide had no significant effects on the accumulation of DOPA and 5-HTP. After exposure to hypoxia, the accumulation of DOPA and 5-HTP was markedly decreased as compared with the values obtained under room air. Under hypoxic conditions, $100 \mathrm{mg} / \mathrm{kg}$ of cinepazide produced no significant changes in the accumulation of DOPA and 5-HTP.

\section{Discussion}

After exposure to hypoxia, the accumulation of DOPA and 5-HTP after treatment with NSD 1015, an index of the in vivo tyrosine and tryptophan hydroxylation, respectively, was decreased. Since tyrosine hydroxylase and tryptopian hydroxylase are considered to be the rate-limiting steps in the biosynthesis of catecholamines $(16,17)$ and $5-\mathrm{HT}(18,19)$, respectively, the present results suggest that the biosynthesis of catecholamines and 5-HT are decreased under hypoxia. These results are in good agreement with the previous reports (5-8). However, since DOPA is a common precursor for the biosynthesis of NA and DA, it is unknown whether this decrease in DOPA accumulation observed under hypoxia is due to the decrease in DOPA formation in NA neurons, DA neurons or both. Therefore, we estimated the rate of biosynthesis of NA and DA from the content and the turnover rate of NA and DA. Under hypoxic conditions, the content of NA was decreased, whereas the turnover rate of NA was unchanged. On the other hand, the content of DA was unchanged under hypoxia, whereas the turnover rate of DA was markedly decreased. These results taken together suggest that DOPA accumulation was decreased under hypoxia both in NA neurons and in DA neurons. However, considering that the conversion of exogenously administered DOPA to NA was decreased under hypoxia (9), the decrease in NA biosynthesis may be partly due to the inhibition of dopamine $\beta$-hydroxylase by hypoxia.

After exposure to hypoxia, the depletion of DA after treatment with $\alpha$-MT was markedly retarded, whereas the depletion of NA was almost unchanged. These results are in good agreement with the previous results $(8,9)$. Furthermore, as previously reported by us (8), the present results showed that the depletion of 5-HT after synthesis inhibition was retarded by hypoxia. Since the turnover rate of a neurotransmitter is considered to be a good biochemical index of the functional activities of the neurons containing the neurotransmitter $(20,21)$, these data indicate that the functional activities of NA neurons are relatively resistant to hypoxia, whereas the activities of DA and 5-HT neurons are sensitive to hypoxia. The decrease in 5 - HIAA content, which is also regarded as a good biochemical index of the turnover rate of 
5-HT (22), provides another evidence that hypoxia decreases the turnover rate of $5-\mathrm{HT}$. However, the decrease in 5-HIAA content observed under hypoxia may be partly due to the inhibition of monoamine oxidase, since this enzyme requires molecular oxygen as a substrate. These results taken together suggest that although hypoxia inhibits the biosynthesis of NA, DA and 5-HT in the brain, the functional activities of only DA and 5-HT neurons are affected by hypoxia.

Although it is reported that cinepazide has a vasodilating action and increases the cerebral blood flow (1-3), cinepazide had no effects on the content of NA, DA, 5-HT and 5-HIAA, the accumulation of DOPA and 5-HTP, and the depletion of NA, DA and 5-HT after synthesis inhibition under room air. These results suggest that a mere increase in the cerebral blood flow induced by cinepazide has no significant effects on the biosynthesis and turnover rates of NA, DA and 5-HT in the brain.

Under hypoxic conditions, cinepazide had no significant effects on the content of NA and DA, DOPA accumulation and the turnover rates of NA and DA. The accumulation of 5-HTP was also not affected by hypoxia. However, cinepazide counteracted the hypoxia-induced retardation of $5-\mathrm{HT}$ depletion and increased the content of 5HIAA. These results suggest that under hypoxic conditions, cinepazide improves selectively the functional activities of $5-\mathrm{HT}$ neurons, which are depressed by hypoxia. Since it is reported that exposure to hypoxia increases the cerebral blood flow (23), this stimulatory effect of cinepazide on the functional activities of 5 - HT neurons may be due to an action other than increasing the cerebral blood flow. The mechanisms of action of cinepazide under hypoxic conditions are now under investigation.

Acknowledgment: The authors wish to express their gratitude to Daiichi Seiyaku Co., Ltd. for the generous donation of the hypoxic chamber.

\section{References}

1 Akashi, A., Hirohashi, M., Suzuki, I., Shibamura, S. and Kasahara, A.: Cardiovascular pharmacology of cinepazide, a new cerebral vasodilator. Folia Pharmacol. Japon. 75, 507-516 (1979)
(Abs. in English)

2 Hirohashi, M. and Hagihara, Y.: Effects of 1 - ((1pyrrolidynylcarbonyl) methyl) - 4 - (3,4,5 - trimethoxycinnamoyl) piperazine maleate (cinepazide) on cerebral and peripheral circulation in cats. Folia Pharmacol. Japon. 75, 495-506 (1979) (Abs. in English)

3 Baba, M. and Kitamura, K.: The effects of cinepazide on cerebral circulation. Brain and Nerve 31, 91-99 (1979)

4 Atarashi, J., Araki, G., Ito, H., Otomo, E., Kase, M. and Kameyama, M.: Clinical evaluation of cinepazide in the treatment of cerebrovascular disorders. Multi-center double-blind study in comparison with placebo. Rinshyo Hyoka 7 , 349-377 (1979)

5 Davis, J.N. and Carlsson, A.: Effects of hypoxia on tyrosine and tryptophan hydroxylation in unanaesthetized rat brain. J. Neurochem. 20, 913-915 (1973)

6 Davis, J.N. and Carlsson, A.: The effects of hypoxia on monoamine synthesis, levels and metabolism in rat brain. J. Neurochem. 21, 783-790 (1973)

7 Brown, R.M., Snider, S.R. and Carlsson, A.: Changes in biogenic amine synthesis and turnover induced by hypoxia and/or foot shock stress. II. The central nervous system. J. Neural Transm. 35, 293-305 (1975)

8 Inoue, M., Miwa, S., Fujiwara, M. and Fujiwara, M.: Effects of hypoxia on the monoaminergic neuron system in the rat brain. Japan. J. Pharmacol. 36, Supp. 314P (1984)

9 Brown, R.M., Kehr, W. and Carlsson, A.: Functional and biochemical aspects of catecholamine metabolism in brain under hypoxia. Brain Res. 85, 491-509 (1975)

10 Keller, R., Oke, A., Mefford, I. and Adams, R.N.: Liquid chromatographic analysis of catecholamines. Routine assay for regional brain mapping. Life Sci. 19, 995-1004 (1976)

11 Miwa, S., Watanabe, Y. and Hayaishi, O.: 6R-L-Erythro-5,6,7.8-tetrahydrobiopterin as a regulator of dopamine and serotonin biosynthesis in the rat brain. Arch. Biochem. Biophys. 239, 234-241 (1985)

12 Reinhard, R.G., Jr., Moskowitz, M.A., Sved, A.F. and Fernstrom, J.D.: A simple, sensitive and reliable assay for serotonin and 5-HIAA in brain tissue using liquid chromatography with electrochemical detection. Life Sci. 27, 905-911 (1980)

13 Carlsson, A., Davis, J.N., Kehr, W., Lindquist, M. and Atack, C.V.: Simultaneous measurement of tyrosine and tryptophan hydroxylase activities 
in brain in vivo using an inhibitor of the aromatic amino acid decarboxylase. Naunyn Schmiedebergs Arch. Pharmacol. 275, 153-168 (1972)

14 Brodie, B.B., Costa, E., Dlabac, A., Neff, N.H. and Smookler, H.H.: Application of steady state kinetics to the estimation of synthesis rate and turnover time of tissue catecholamines. J. Pharmacol. Exp. Ther. 154, 493-498 (1966)

15 McGeer, E.G., Peters, D.A.V. and McGeer, P.L.: Inhibition of rat brain tryptophan hydroxylase by 6-halotryptophan. Life Sci. 7, 605-615 (1968)

16 Nagatsu, T., Levitt, M. and Udenfriend, S.: Tyrosine hydroxylase. The initial step in norepinephrine biosynthesis. J. Biol. Chem. 239, 2910-2917 (1964)

17 Udenfriend, S.: Tyrosine hydroxylase. Pharmacol. Rev. 18, 43-51 (1966)

18 Ichiyama, A., Nakamura, S., Nishizuka, Y. and Hayaishi, O.: Tryptophan hydroxylase in mammalian brain. Adv. Pharmacol. 6A, 5-17 (1968)

19 Chase, T.N., Breese, G.R., Carpentar, D.O.,
Schanberg, S.M. and Kopin, I.J.: Stimulationinduced release of serotonin. Adv. Pharmacol. 6A, 351-364 (1968)

20 Korf, J.: The turnover of neurotransmitters in the brain: An introduction. In Central Neurotransmitter Turnover, Edited by Pycock, C.J. and Taberner, P.V., p. 1-19, Croom Helm, Ltd., London (1981)

21 Sharman, D.F.: The turnover of catecholamines. In Central Neurotransmitter Turnover, Edited by Pycock, C.J. and Taberner, P.V., p. 20-58. Croom Heim, Ltd., London (1981)

22 Curzon, G.: The turnover of 5-hydroxytryptamine. In Central Neurotransmitter Turnover, Edited by Pycock, C.J. and Taberner, P.V., p. 59-80, Croom Helm, Ltd., London (1981)

23 Poncin-Lafitte, M.Le, Pesquies, P.C. and Rapin, J.R.: Correlation between brain blood flow and catecholamine levels in rat brain areas under hypobaric hypoxia. Experientia 36, 1405-1406 (1980) 